IdeAs

Idées d'Amériques

$10 \mid 2017$

États-Unis / Cuba : une nouvelle donne?

\title{
Matthew E. Stanley, The Loyal West. Civil War and Reunion in Middle America
}

Urbana: University of Illinois Press, 2016, 268 p.

Nathalie Massip

\section{CpenEdition}

\section{Journals}

Édition électronique

URL : https://journals.openedition.org/ideas/2182

DOI : $10.4000 /$ ideas. 2182

ISSN : 1950-5701

Éditeur

Institut des Amériques

Référence électronique

Nathalie Massip, «Matthew E. Stanley, The Loyal West. Civil War and Reunion in Middle America », IdeAs [En ligne], 10 | 2017, mis en ligne le 18 décembre 2017, consulté le 19 octobre 2022. URL : http:// journals.openedition.org/ideas/2182 ; DOI : https://doi.org/10.4000/ideas.2182

Ce document a été généré automatiquement le 19 octobre 2022.

\section{c) (i) $\ominus$}

Creative Commons - Attribution - Pas d'Utilisation Commerciale - Pas de Modification 4.0 International - CC BY-NC-ND 4.0

https://creativecommons.org/licenses/by-nc-nd/4.0/ 


\title{
Matthew E. Stanley, The Loyal West. Civil War and Reunion in Middle America
}

Urbana: University of Illinois Press, 2016, 268 p.

\author{
Nathalie Massip
}

\section{RÉFÉRENCE}

Matthew E. Stanley, The Loyal West. Civil War and Reunion in Middle America. Urbana:

University of Illinois Press, 2016, 268 p.

1 Matthew Stanley's The Loyal West. Civil War and Reunion in Middle America, focuses on the Lower Middle West, and its contribution to the Civil War and reconciliation that followed. While the "Loyal West" of the title comprises the states of Ohio, Indiana, and Illinois, Stanley also examines the subregion's relations to the larger Ohio River Valley, especially to its Southern neighbor, Kentucky.

2 As Stanley demonstrates, the region had long attracted settlers from both the North and the South, creating a typically western identity that rested on moderation, conservatism, and accommodation between freedom and slavery. The Lower Middle West, home to both Democratic followers of Stephen Douglas and free labor Republicans, distinguished itself at the onset of the Civil War by becoming a staunch supporter of Unionism. Following Douglas' rejection of neutrality (“There can be no neutrals in this war, only patriots and traitors."), volunteers joined Union troops by the thousands. Even Southern Illinois, a historically Democratic region, "enlisted a higher percentage of soldiers than any other region in the Union" (49), as Stanley points out.

3 Not only was this West "loyal," it was also very conservative in its outright rejection of emancipation: "emancipation was met with more hostility in the Lower Middle West than in any part of the free states, with civilians and soldiers alike far more likely to accept the measure as a war means rather than a war aim, as strategy rather than 
policy." (59, italics in the text) Fighting alongside Northerners for the preservation of the Union did not prevent many Lower Middle Westerners from sharing their Secessionist enemies' views on race, including-if not even more so-after Lincoln's Preliminary Emancipation Proclamation of September 1862.

The conservatism of the region was even more forceful in the aftermath of the war, to the point that the region played a major role in the failure of Reconstruction, according to Stanley: "Reconstruction ultimately failed as a set of national policies because it failed first as a mental re-imagining of social and economic relations in the part of the North where it was most vulnerable: Middle America's conservative Unionist belt." (100) The historian contends that, as a bellwether region, the Lower Middle West set the tone for the rest of the country. Not only did its deeply entrenched racism doom Reconstruction in the region and, as a result, in the nation at large; but the rejection of emancipation evolved into racial exclusivism and violent expressions of white supremacy.

5 The originality of Stanley's analysis rests in the links he establishes between sectionalism and regionalism. Beyond the traditional emphasis on the North-South divide characterizing the Civil-War era United States, the East-West sectional division that Stanley highlights is compelling. Despite its southern attributes, the region was anti-rebel. Yet it was also anti-eastern, in spite of-if not because of-the "Yankee invasion" the region experienced from the 1830s on. Most significantly, Lower Middle Westerners were consistently anti-black. Defined as "the defiant insistence that the region's interests lay neither with North nor South," (65) the peculiarly western identity the historian describes in this Middle America sheds new light on the region.

The book also underscores the centrality, significance, and versatility of the Ohio River. During the war, the latter was seen as separating the "loyal West" from the South. It not only divided slave from free but, also, delineated loyalty and disloyalty, as Kentucky, on the opposite bank, was seen as "the land of the traitor and the home of the slave" (52). Yet the "loyalty line" morphed into a "reconciliation line" following the war: "By the mid-1880s, Union and confederate veterans were using the Ohio River as a reunion apparatus by imagining it not as a sectional boundary but as they had during the antebellum period, as a cultural connector." (167)

7 Finally, Stanley skillfully combines regionalism and Civil War memorialization, examining the "Loyal West" narrative that emerged after the war in counterpoint to the "Two Americas" thesis. Asserting their political and cultural distinctiveness, veterans of western armies claimed that they had won the war, and depicted their loyalty as superior to their eastern counterparts'. Regionalism was also central to reconciliation, according to Stanley. By the 1880s, "drawing on their shared western and conservative identities with one-time enemies in Kentucky, Missouri, and Tennessee," (155) the Lower Middle West reconciled with the former Confederacy, therefore splitting with the Loyal West. As lines were redrawn and the country moved further West, the regional uniqueness of the Loyal West "paved the way in part for the Midwest-an anti-section marked by the values of the prairie and Main Street, the river valleys and the urban polyglot." (182)

8 The Loyal West is a well-researched, compact, and deft examination that rests on soldiers' and officers' memoirs and letters, for the most part. A most welcome map of the Lower Middle West in 1860 opens the book, while a few relevant illustrations (including maps of Southern Illinois showing the shifts in the five presidential elections 
of the Civil-War and Reconstruction eras, from Democratic to Republican, then Democratic again), as well as appendixes made of charts providing county returns for each presidential election year from 1860 to the end of Reconstruction accompany Stanley's well-written text. Overall, it is a very valuable and welcome analysis that sheds light on an often-understudied region and its identity, and uncovers its complex and crucial role in Civil-War era America. It is also timely, especially in light of recent renewed interest in Midwestern studies. Therefore, it is to be hoped that The Loyal West will open the way to more studies of the same kind and quality.

\section{AUTEURS}

\section{NATHALIE MASSIP}

MCF études américaines, Université Nice Sophia Antipolis, membre de l'Université Côte d'Azur (UCA) 